\title{
Consequence of alternative standards for bulk tank somatic cell count of dairy herds in the United States
}

\author{
H. D. Norman, ${ }^{\star 1}$ J. E. Lombard,† J. R. Wright, ${ }^{*}$ C. A. Kopral,† J. M. Rodriguez, † and R. H. Miller \\ *Animal Improvement Programs Laboratory, Agricultural Research Service, USDA, Beltsville, MD 20705-2350 \\ †Centers for Epidemiology and Animal Health, Veterinary Services, Animal and Plant Health Inspection Service, USDA, \\ Fort Collins, CO 80526-8117
}

\section{ABSTRACT}

Noncompliance with current US and European Union (EU) standards for bulk-tank somatic cell count (BTSCC) as well as BTSCC standards recently proposed by 3 US organizations was evaluated using US Dairy Herd Improvement Association (DHI) herds and herds supplying milk to 4 Federal Milk Marketing Orders (FMO). Herds with 15 to 26 tests (frequently monthly) from January 2009 through October 2010 were included. Somatic cell scores (SCS) from 14,854 herds and 164,794 herd-tests were analyzed for DHI herds with $\geq 10$ cows for all tests. Herd test-day SCC was derived as a proxy for BTSCC and was the basis for determining noncompliance and percentage of the milk it represented. For FMO herds, actual milk marketed and BTSCC were available from 27,759 herds and 325,690 herd-tests. A herd was noncompliant for the current EU BTSCC standard after 4 consecutive rolling 3-test geometric means (geometric method) were $>400,000$ cells $/ \mathrm{mL}$. A herd was noncompliant for the current US BTSCC standard after 3 of 5 consecutive monthly BTSCC shipments (frequency method) were $>750,000$ cells $/ \mathrm{mL}$. Alternative proposed standards $(600,000,500,000$, or 400,000 cells $/ \mathrm{mL})$ also were examined. A third method designated noncompliance when a single 3 -mo geometric mean of $>550,000$ or $>400,000$ cells $/ \mathrm{mL}$ and a subsequent test exceeded the same level. Results were examined based on herd size or milk shipped by month. Noncompliance for the current US standard for the 12 mo ending October 2010 in DHI and FMO herds was 0.9 and $1.0 \%$, respectively, compared with 7.8 and $16.1 \%$ for the current EU standard. Noncompliance was always greater for the frequency method than for the geometric method and was inversely related to herd size or milk shipped. Using the frequency method at 400,000 cells/mL, noncompliance was $19.1 \%$ for DHI herd-tests in herds with $<50$

Received June 21, 2011.

Accepted September 1, 2011.

${ }^{1}$ Corresponding author: Duane.Norman@ars.usda.gov cows compared with $1.1 \%$ for herds with $\geq 1,000$ cows. For FMO herds shipping $<900 \mathrm{t}$, noncompliance was $44.5 \%$ using the frequency method at 400,000 cells $/ \mathrm{mL}$ compared with $8.0 \%$ for herds marketing $>9,000 \mathrm{t}$. All methods proposed increased the percentages of herds and shipped milk that exceeded the regulatory limit. Producers will need to place more emphasis on reducing the incidence and prevalence of subclinical mastitis through known management practices such as proper milking techniques, well-functioning milking machines, postmilking teat disinfectant, dry cow treatment, and culling of problem cows to meet any of the proposed new standards.

Key words: European Union, milk quality, somatic cell count, standard

\section{INTRODUCTION}

Somatic cells are a combination of secretory cells, squamous cells, and white blood cells (leukocytes and macrophages) present in milk. White blood cells increase in the presence of bacterial infections in the udder and are responsible for combating infections. The influence of mastitis management practices on bulk tank SCC (BTSCC) has been evaluated in several studies and reviewed by Barkema et al. (1999) and more recently by Dufour et al. (2011). Among the important factors for the prevention of a high BTSCC are postmilking teat disinfection, dry cow therapy, good milking management, treatment of clinical mastitis, and culling of problem cows. Type of milking equipment, housing facilities, and general cow management also are influencing factors.

The SCC is a general reflection of milk quality; therefore, most countries establish a maximum limit for BTSCC from each farm. In 1991, the National Conference on Interstate Milk Shipments (NCIMS) recommended lowering the US standard for somatic cells in grade A milk from 1.0 million to 750,000 cells/ $\mathrm{mL}$ (FDA, 1991), and that standard was implemented in July 1993 (FDA, 1993). The rationale for the lower standard was that concerns about negative effects on 
human health would be alleviated (Spomer, 1998). The maximum BTSCC imposed by most other major dairy countries is lower than that in the United States: 400,000 cells/mL in the European Union (EU; Europa, 2009), Australia (Brightling et al., 2005), and New Zealand (New Zealand Food Safety Authority, 2010) and 500,000 cells/mL in Canada (Canadian Food Inspection Service, 2005).

Differences in national standards become a factor if a country wants to export to another country that has more restrictive limits. To prevent trade barriers that restrict imports, the World Trade Organization (1998) prohibits more stringent standards for imported than domestic products. Since 2004, the EU BTSCC standard for milk imports has been certified in the United States by sampling milk pooled from several farms (Agricultural Marketing Service, 2009; Burggraff, 2010). However, an EU audit in 2009 resulted in a declaration that future importation would require each individual farm to meet that standard (National Milk Producers Federation, 2010a). From that development, and because the EU standard is more restrictive, the US FDA has come under political pressure not only to intervene (Johnson, 2010) but to tighten the US standard for milk sold through domestic markets (Gillibrand, 2010); US Senator Kristen Gillibrand (New York) proposed US Senate bill 458 (govtrack.us, 2011) to change the standard. A herd would become noncompliant for the EU BTSCC standard when 4 consecutive rolling 3-test geometric means (designated as the geometric method) exceeded 400,000 cells/mL.

Some large dairy processors have already imposed the EU standard on their producers (R. Clauss, Hilmar Cheese Company, Hilmar, CA; personal communication). Idaho and Oregon recently lowered state standards to 500,000 cells/mL (Dumas, 2010). Canada will lower its BTSCC standard from 500,000 to 400,000 cells/mL in August 2012 (A. Godkin, Veterinary Science and Policy Unit, Ontario Ministry of Agriculture, Food, and Rural Affairs, Elora, ON, Canada; personal communication). In October 2010, the National Milk Producers Federation (NMPF) recommended that NCIMS lower the US BTSCC standard in 3 steps: from 750,000 to 600,000 cells $/ \mathrm{mL}$ on January 1,2012 , to 500,000 cells/mL on January 1, 2013, and to 400,000 cells/mL on January 1, 2014 (National Milk Producers Federation, 2010b). The NMPF resolution called for a continuation of current regulatory enforcement: a warning to a producer when 2 of the last 2, 3, or 4 BTSCC tests exceed the limit, and suspension whenever 3 of 3 , 4 , or 5 consecutive tests fail (designated as the frequency method). The National Mastitis Council (NMC) followed with a somewhat similar recommendation but proposed replacing the frequency method with the geometric method and implementing a single transition $(550,000$ cells $/ \mathrm{mL})$ before a final SCC standard of 400,000 cells/mL (A. Saeman, NMC, Verona, WI; personal communication). The National DHIA (NDHIA) passed a resolution asking NMPF to reconsider its proposal to NCIMS and use the geometric rather than the frequency method with transitions at 600,000, 500,000, and 400,000 cells/mL (J. Mattison, NDHIA, Verona, WI; personal communication). In May 2011, NCIMS voted on changing the US standard, but the vote failed (National Milk Producers Federation, 2011). However, many individual milk processors are starting to require stricter standards even though NCIMS voted to leave the US standard unchanged (Maryland \& Virginia Milk Producers Cooperative Association, 2011).

More herds will be designated as noncompliant for SCC if either the EU BTSCC standard is enforced for herds producing for export or any of the other proposals are implemented for domestic milk. Adkinson et al. (2001) examined the effect of changing standards for herds in Louisiana, Mississippi, and West Texas, and found a 2-fold increase in regulatory actions for each 100,000-cell decrease in BTSCC below 750,000 cells/ $\mathrm{mL}$. A current prediction of the exact extent of the increased noncompliance is not easy to obtain because BTSCC from many of the US dairy farms are not readily available to researchers. Information from 2 sources of BTSCC data have been reported on an annual basis: DHI records and Federal Milk Marketing Orders (FMO). The FMO data from 4 orders represent $45.5 \%$ of milk produced in the United States (Veterinary Services, 2010), whereas DHI data represent 45 to $50 \%$ of dairy operations and cows in the United States (USDA, 2007). Because $95 \%$ of DHI herds are SCC tested (Animal Improvement Programs Laboratory, 2011), DHI SCC have been used as an alternative to BTSCC to provide SCC trends by state, herd size, month, and year (Norman et al., 2011a,b). Means from a herd's DHI test-day SCC might be expected to be slightly higher than the herd's BTSCC because milk with quality issues is excluded from the bulk tank to comply with food safety and milk quality regulations and avoid financial penalties for high-SCC milk. Nevertheless, means and especially trends for US DHI SCC and BTSCC from FMO have been reasonably close (Norman et al., 2000). However, Lievaart et al. (2009) did not find this similarity in a comparison between SCC and BTSCC means in the Netherlands.

As a result of dramatic declines in BTSCC during the last decade (Veterinary Services, 2007, 2010; Norman, 2010), the US mean for BTSCC is currently lower than that of several other major dairy countries that publish their BTSCC data (J. E. Lombard, unpublished data). The DHI and FMO data complement each other in that 
they represent different segments of the industry. The DHI data are nationwide but lack herds not enrolled in milk recording. The FMO data include such herds but are regional and lack the southern and southeastern United States along with many of the high-yielding herds from the west coast.

The objective of this research was to examine noncompliance rates of US herds for current EU and US BTSCC standards as well as for several BTSCC standards proposed by 3 US organizations. Amounts of milk supplied by potentially noncompliant herds also were examined.

\section{MATERIALS AND METHODS}

\section{Data}

DHI. Data included individual cow's milk yield and SCS from the US national dairy database for 14,854 DHI herds and 164,794 herd-tests. Herds were required to have 15 to 26 DHI SCC tests from January 2009 through October 2010 and $\geq 10$ cows for all test days. Individual cow SCC were derived from the SCS using $\mathrm{SCC}=2^{(\mathrm{SCS}-3)}(100,000)$. Herd test-day SCC was used as a proxy for BTSCC and was derived by weighting each cow's SCC by her test-day milk yield. For some results, only 12 mo of data (November 2009 through October 2010) were used.

FMO. Data were obtained from 4 FMO (Upper Midwest, Central, Mideast, and Southwest) on a monthly basis and included producer identification, date, FMO milk quantity produced for the month, and official herd BTSCC. Total number of herds represented was 27,759, and total number of herd-tests (shipments) monitored was 325,690 .

\section{Geometric Method}

For the current EU SCC standard (Europa, 2009), bulk tank milk samples are generally taken at the farm at least once per month and tested for SCC. The most recent BTSCC is used along with the herd's 2 previous BTSCC to calculate the geometric mean $\left(\overline{\mathbf{S C C}}_{g}\right)$ : $\overline{\mathrm{SCC}}_{g}=\sqrt[3]{\left(\mathrm{SCC}_{1}\right)\left(\mathrm{SCC}_{2}\right)\left(\mathrm{SCC}_{3}\right)}$. If $\overline{\mathrm{SCC}}_{g}$ is $>400,000$ cells $/ \mathrm{mL}$, the herd is put on a watch list. The BTSCC of the next 3 tests for any herd placed on the watch list are used to calculate additional rolling 3 -test $\overline{\mathrm{SCC}}_{g}$, which are reviewed to determine whether the herd's milk continues to enter the pool that might be marketed to the EU. The herd is removed from the watch list if any of the next 3 tests produce a 3 -test $\overline{\mathrm{SCC}}_{g}$ of $\leq 400,000$ cells $/ \mathrm{mL}$. If $\overline{\mathrm{SCC}}_{g}$ is $>400,000$ cells $/ \mathrm{mL}$ for all 3 of the additional tests, the herd is suspended from marketing; that is, after the sixth test. The EU 3-test probationary period provides considerable opportunity (about $5 \mathrm{mo}$ ) to make management changes to lower herd $\overline{\mathrm{SCC}}_{g}$ before a herd can become noncompliant. Almost all major dairy countries use the geometric mean for their standard. Using a geometric mean derived from 3 monthly tests minimizes the volatility in herd BTSCC observed when one extreme cow would otherwise have a major effect on the herd SCC or from fluctuations due to season or adverse weather conditions. Further advantages of the geometric method were discussed by The International Dairy Federation (1997) and Shook and Ruegg (1999).

The geometric method proposed by NMC uses a shorter testing interval for both the transitional SCC standard of 550,000 cells $/ \mathrm{mL}$ and the final standard of 400,000 cells $/ \mathrm{mL}$. If the geometric mean exceeds the SCC standard, a single subsequent test is taken $3 \mathrm{wk}$ later to determine the marketing consequence; that is, the herd becomes noncompliant if it still exceeds the SCC standard. The NMC 4-test period monitoring allows $<3$ mo to lower herd $\overline{\mathrm{SCC}}_{g}$ before a herd might become noncompliant.

\section{Frequency Method}

For the current US BTSCC standard (FDA, 2009), bulk tank milk samples are taken at the farm and tested for BTSCC. If 3 of 5 consecutive test samples are $>750,000$ cells $/ \mathrm{mL}$, the herd must discontinue marketing its milk as grade A until it comes back into compliance. One additional high test will make a herd noncompliant immediately when 2 of the 2,3 , or 4 previous BTSCC have already been $>750,000$ cells $/ \mathrm{mL}$. The frequency method allows 2 to 4 mo to monitor a herd's SCC before declaring it noncompliant. The same strategy would be maintained to determine compliance using the 3 annual transitional SCC standards proposed by NMPF $(600,000,500,000$, and 400,000 cells/mL).

\section{Analysis}

Percentage of herd-tests resulting directly in noncompliance for each BTSCC standard (current US or EU or proposed NMPF, NMC, or NDHIA) was the number of violations that triggered noncompliance divided by the number of occasions on which such an outcome could have been made. Those results differ from known previous reports in that noncompliance is determined the same as it is in field operations; that is, based on multiple, consecutive samples, in contrast to simply reporting the percentage of individual months that exceed a specified BTSCC.

Differences among the 10 alternative BTSCC standards were determined by examination of standard 
errors derived for each alternative. Because compliance was a binomial, standard error was calculated as standard deviation divided by the square root of the number of observations on which each compliance rate was based. Standard errors were derived from data for the entire year rather than from data each month or from herd-size groups.

Herd and herd-test BTSCC compliance for current and proposed standards was examined by month, herd size, or annual milk marketed. Groups for DHI herd size were 10 to 49,50 to 99,100 to 149,150 to 199,200 to 299,300 to 499,500 to 999 , and $\geq 1,000$ cows. For FMO data, annual milk marketed categories were created to represent herds of $<100$ cows, 100 to 499 cows, 500 to 999 cows, and $\geq 1,000$ cows. A rolling herd mean for milk production of $9,000 \mathrm{~kg} / \mathrm{cow}$ per yr was used to estimate the number of cows per herd. Milk marketed was categorized into 4 groups: $<900,900$ to 4,500 , 4,501 to 9,000 , and $>9,000$ t. For all proposed standards, noncompliance rate is based on historic BTSCC levels even though management for milk quality would be expected to improve if producers had to cope with stricter standards. In addition to providing compliance rates triggered by herd-tests, the percentage of herds that would be noncompliant at least once during the year was determined. Pearson correlations between the various alternative methods were calculated using compliance as the herd-test measurement examined (0 $=$ noncompliant, $1=$ compliant .

\section{RESULTS}

\section{Effects of BTSCC by Month}

Percentage of DHI herds that became noncompliant monthly from June 2009 through October 2010 ranged from 0.6 to $1.2 \%$ for the current US standard and would have been from 7.0 to $8.9 \%$ for the EU standard (Table 1). Mean monthly noncompliance rate for standards proposed by NMPF ranged from 2.1 to $3.3 \%$ for 600,000 cells $/ \mathrm{mL}, 5.2$ to $7.4 \%$ for 500,000 cells $/ \mathrm{mL}$, and 12.3 to $16.4 \%$ for 400,000 cells $/ \mathrm{mL}$. For each BTSCC standard, noncompliance was generally lowest in January or February and highest in September or October.

Mean percentage of DHI herd-tests that triggered noncompliance for current BTSCC standards based on tests from November 2009 through October 2010 was $0.9 \%$ for the United States and $7.8 \%$ for the EU (Table 1). Those percentages were weighted by the number of herds tested in each month. The DHI noncompliance rates for standards proposed by NMPF would have been $2.7 \%$ for $600,000,6.2 \%$ for 500,000 , and $14.1 \%$ for 400,000 cells $/ \mathrm{mL}$ if herd management had not been changed to alleviate the tightening of BTSCC regula- tions. The first 2 incremental decreases that NMPF proposed for the US standard were less restrictive than the EU standard, but the third (final) decrease was considerably more restrictive. An incremental decrease of the BTSCC limit between 500,000 and 400,000 cells/ $\mathrm{mL}$ using the frequency method (3 of 5 BTSCC tests) revealed that a standard of 472,000 cells $/ \mathrm{mL}$ would result in a herd noncompliance rate equal to that for the current EU standard ( $7.8 \%$ of herds).

Both NDHIA and NMC supported the adoption of the geometric method once they realized those standards would not be as disruptive as those from the frequency method. Percentages of noncompliance for the geometric method (middle section, Table 1) were only one-third to one-half as high as those from the frequency method (left section, Table 1). Mean noncompliance rates for the frequency method were 0.9 , $2.7,6.2$, and $14.1 \%$ for BTSCC standards of 750,000 , $600,000,500,000$, and 400,000 cells/mL, respectively, compared with $0.3,1.1,2.9$, and $7.8 \%$ for the geometric method.

The NMC-proposed BTSCC standards of 550,000 and 400,000 cells/mL (right section, Table 1) resulted in a mean noncompliance rate of 2.3 and $9.0 \%$, respectively, which was slightly more restrictive than the EU method but addressed milk quality concerns sooner (i.e., in $<3$ instead of $5 \mathrm{mo}$ ). All 10 alternative BTSCC standards shown in Table 1 produced noncompliance rates that differed significantly $(P<0.001)$ from each other as revealed through the extremely small SE associated with the means (0.01 to 0.09).

Percentage of FMO herd-tests that were noncompliant for the current US standard was $1.0 \%$ (Table 2) compared with $0.9 \%$ for DHI herd-tests. Percentage of FMO herd-tests that were noncompliant for NMPFproposed limits of $600,000,500,000$, and 400,000 cells/ $\mathrm{mL}$ was $4.7,11.0$, and $23.3 \%$, respectively. Those percentages represent almost double the percentage of DHI herds that were noncompliant. The lowest percentage of noncompliant shipments occurred during the winter months (December to February). Similar to DHI herds, the highest percentage of noncompliance occurred in September and October. A smaller percentage would have been noncompliant using the EU standard (geometric method) compared with the frequency method at 400,000 cells $/ \mathrm{mL}$ (16.1 and $23.3 \%$, respectively), whereas the NMC proposal was only slightly more restrictive than the EU standard (17.4\%). Again, all but 2 (NMPF at 600,000 cells/mL and NMC at 550,000 cells $/ \mathrm{mL}$ ) of the alternative standards shown in Table 2 resulted in noncompliance rates that differed significantly $(P<0.001)$ from each other as evidenced by the extremely small SE associated with the means (0.01 to 0.07). In addition, the SE in Tables 1 and 2 confirmed 
Table 1. Percentages of US DHI herd-tests ${ }^{1}$ noncompliant for bulk tank SCC (BTSCC) based on various standards by month

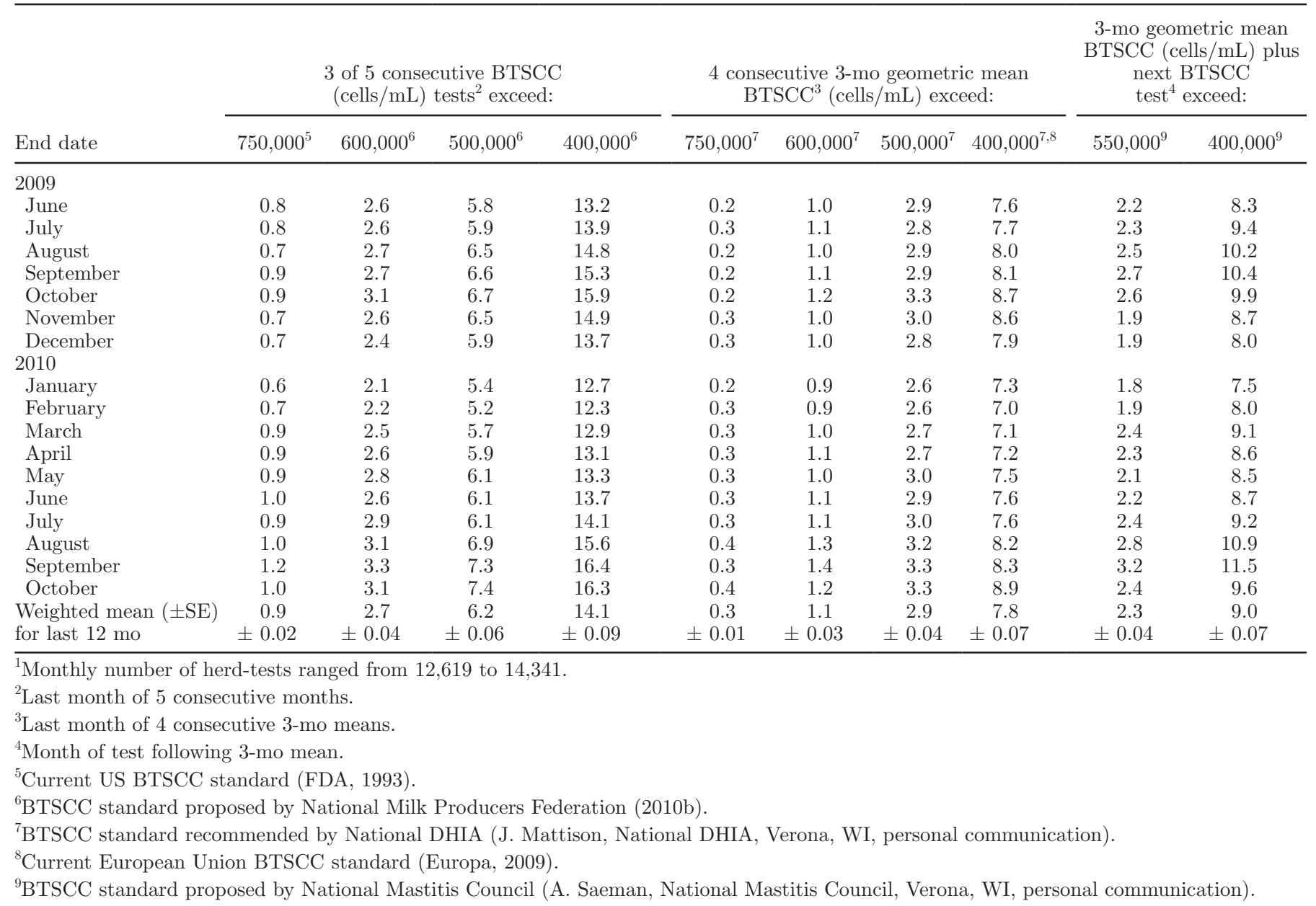

that the noncompliance rate was significantly higher for the FMO herds than for the DHI herds for all 10 alternatives and was only close for the current US standard.

Table 3 helps reveal why many more FMO herds became noncompliant under the stricter BTSCC standards than did the DHI herds. The unweighted BTSCC herd means for both data sets were considerably higher (47,000 cells/mL higher for DHI herds and 62,000 cells/ $\mathrm{mL}$ higher for FMO herds) than when herd-tests were weighted for milk yield, the latter representing the total milk produced. The DHI herd-tests (unweighted for herd yield) averaged 275,000 cells/mL, whereas the unweighted FMO herds averaged 314,000 cells $/ \mathrm{mL}$. The respective means weighted for herd milk yield were 228,000 and 252,000 cells/mL. The standard deviations of herd-tests were quite similar for DHI and FMO herds at 171,000 and 165,000 cells/mL, respectively, and were related positively to the mean.

The effect of noncompliance on the total milk supply (Tables 4 and 5) was less severe than its effect on the number of milk producers (Tables 1 and 2). Percentage of the US milk supply from DHI herds that were BTSCC noncompliant based on tests from November 2009 through October 2010 was 0.2 for the current US standard and 3.1 for the current EU standard (Table 4). The milk supply from DHI herds that would have been noncompliant for proposed NMPF standards without improved herd management was $0.7 \%$ for 600,000 , $2.0 \%$ for 500,000 , and $5.8 \%$ for 400,000 cells $/ \mathrm{mL}$. The noncompliant milk supply using NDHIA-recommended standards was lower at $0.3,1.0$, and $3.1 \%$, respectively, and was 0.7 and $3.7 \%$ for the NMC-recommended standards of 550,000 and 400,000 cells/mL, respectively. Percentage of US DHI milk that became BTSCC noncompliant monthly from June 2009 through October 2010 ranged from 0.1 to $0.3 \%$ for the current US standard and from 2.8 to $3.6 \%$ had the EU standard been imposed. For proposed NMPF incremental standards, monthly milk supply from noncompliant herds ranged from 0.6 to $1.0 \%$ for 600,000 cells $/ \mathrm{mL}, 1.8$ to $2.4 \%$ for 500,000 cells $/ \mathrm{mL}$, and 5.2 to $6.9 \%$ for 400,000 cells/ 
Table 2. Percentages of US Federal Milk Marketing Order herd-tests ${ }^{1}$ noncompliant for bulk tank SCC (BTSCC) based on various standards by month

\begin{tabular}{|c|c|c|c|c|c|c|c|c|c|c|}
\hline \multirow[b]{2}{*}{ End date } & \multicolumn{4}{|c|}{$\begin{array}{l}3 \text { of } 5 \text { consecutive BTSCC } \\
\text { (cells } / \mathrm{mL}) \text { tests }^{2} \text { exceed: }\end{array}$} & \multicolumn{4}{|c|}{$\begin{array}{l}4 \text { consecutive } 3 \text {-mo geometric } \\
\text { mean } \text { BTSCC }^{3} \text { (cells } / \mathrm{mL} \text { ) exceed: }\end{array}$} & \multicolumn{2}{|c|}{$\begin{array}{c}\text { 3-mo geometric mean } \\
\text { BTSCC (cells } / \mathrm{mL} \text { ) plus } \\
\text { next BTSCC } \\
\text { test }^{4} \text { exceed: }\end{array}$} \\
\hline & $750,000^{5}$ & $600,000^{6}$ & $500,000^{6}$ & $400,000^{6}$ & $750,000^{7}$ & $600,000^{7}$ & $500,000^{7}$ & $400,000^{7,8}$ & $550,000^{9}$ & $400,000^{9}$ \\
\hline \multicolumn{11}{|l|}{2009} \\
\hline June & 0.9 & 4.7 & 11.3 & 23.4 & 0.3 & 2.4 & 7.0 & 16.9 & 4.3 & 17.8 \\
\hline July & 0.8 & 4.5 & 11.1 & 23.7 & 0.3 & 2.4 & 7.0 & 17.2 & 4.8 & 19.2 \\
\hline August & 0.8 & 4.7 & 11.6 & 24.9 & 0.2 & 2.3 & 7.0 & 17.6 & 5.6 & 20.8 \\
\hline September & 0.9 & 5.1 & 12.0 & 25.8 & 0.3 & 2.3 & 7.1 & 17.9 & 5.2 & 19.5 \\
\hline October & 0.9 & 5.1 & 12.0 & 25.5 & 0.3 & 2.4 & 7.2 & 17.9 & 4.5 & 17.4 \\
\hline November & 0.8 & 4.6 & 11.1 & 24.1 & 0.3 & 2.4 & 6.9 & 17.1 & 4.2 & 16.0 \\
\hline December & 0.7 & 4.0 & 9.9 & 21.7 & 0.2 & 2.1 & 6.3 & 15.8 & 3.8 & 15.1 \\
\hline \multicolumn{11}{|l|}{2010} \\
\hline January & 0.7 & 3.8 & 9.4 & 20.5 & 0.3 & 2.1 & 6.0 & 15.0 & 4.2 & 15.7 \\
\hline February & 0.9 & 4.1 & 9.8 & 20.7 & 0.3 & 2.1 & 5.8 & 14.6 & 4.8 & 16.6 \\
\hline March & 1.0 & 4.9 & 10.9 & 22.0 & 0.4 & 2.2 & 6.2 & 14.8 & 5.3 & 17.7 \\
\hline April & 1.0 & 4.8 & 10.5 & 21.6 & 0.4 & 2.3 & 6.2 & 14.8 & 4.5 & 16.3 \\
\hline May & 1.2 & 5.1 & 11.2 & 23.2 & 0.4 & 2.5 & 6.8 & 16.2 & 4.3 & 16.3 \\
\hline June & 1.0 & 4.4 & 10.6 & 22.4 & 0.4 & 2.4 & 6.6 & 15.8 & 4.6 & 17.4 \\
\hline July & 0.9 & 4.6 & 10.9 & 23.3 & 0.4 & 2.3 & 6.7 & 16.4 & 5.0 & 19.0 \\
\hline August & 1.1 & 5.2 & 11.9 & 26.0 & 0.4 & 2.3 & 6.7 & 16.9 & 6.0 & 21.7 \\
\hline September & 1.3 & 5.6 & 13.1 & 27.7 & 0.4 & 2.4 & 7.0 & 17.5 & 6.1 & 21.8 \\
\hline October & 1.3 & 5.6 & 12.8 & 27.3 & 0.4 & 2.4 & 7.1 & 18.0 & 3.9 & 15.7 \\
\hline Weighted mean $( \pm \mathrm{SE})$ & 1.0 & 4.7 & 11.0 & 23.3 & 0.3 & 2.3 & 6.5 & 16.1 & 4.7 & 17.4 \\
\hline for last $12 \mathrm{mo}$ & \pm 0.02 & \pm 0.04 & \pm 0.05 & \pm 0.07 & \pm 0.01 & \pm 0.03 & \pm 0.04 & \pm 0.06 & \pm 0.04 & \pm 0.07 \\
\hline
\end{tabular}

${ }^{1}$ Monthly number of herd-tests ranged from 24,458 to 30,127 .

${ }^{2}$ Last month of 5 consecutive months.

${ }^{3}$ Last month of 4 consecutive 3-mo means.

${ }^{4}$ Month of test following 3-mo mean.

${ }^{5}$ Current US BTSCC standard (FDA, 1993).

${ }^{6}$ BTSCC standard proposed by National Milk Producers Federation (2010b).

${ }^{7}$ BTSCC standard recommended by National DHIA (J. Mattison, National DHIA, Verona, WI, personal communication).

${ }^{8}$ Current European Union BTSCC standard (Europa, 2009).

${ }^{9}$ BTSCC standard proposed by National Mastitis Council (A. Saeman, National Mastitis Council, Verona, WI, personal communication).

Table 3. Means and standard deviations of US DHI ${ }^{1}$ and Federal Milk Marketing Order (FMO $)^{2}$ herd-tests for BTSCC (1,000 cells $\left./ \mathrm{mL}\right)$ by year and month

\begin{tabular}{|c|c|c|c|c|c|c|}
\hline \multirow[b]{2}{*}{ Year and month } & \multicolumn{3}{|c|}{ DHI SCC } & \multicolumn{3}{|c|}{ FMO SCC } \\
\hline & $\begin{array}{c}\text { Weighted } \\
\text { mean }^{3}\end{array}$ & $\begin{array}{c}\text { Unweighted } \\
\text { mean }^{4}\end{array}$ & $\mathrm{SD}$ & $\begin{array}{l}\text { Weighted } \\
\text { mean }^{3}\end{array}$ & $\begin{array}{c}\text { Unweighted } \\
\text { mean }^{4}\end{array}$ & $\mathrm{SD}$ \\
\hline \multicolumn{7}{|l|}{2009} \\
\hline November & 213 & 255 & 153 & 233 & 294 & 155 \\
\hline December & 214 & 257 & 156 & 234 & 294 & 159 \\
\hline \multicolumn{7}{|l|}{2010} \\
\hline March & 235 & 276 & 179 & 250 & 315 & 173 \\
\hline April & 223 & 263 & 162 & 238 & 299 & 158 \\
\hline May & 220 & 257 & 156 & 236 & 295 & 152 \\
\hline June & 232 & 280 & 173 & 258 & 325 & 164 \\
\hline July & 242 & 297 & 180 & 279 & 351 & 172 \\
\hline August & 252 & 318 & 193 & 290 & 366 & 179 \\
\hline September & 235 & 295 & 178 & 265 & 330 & 160 \\
\hline
\end{tabular}

${ }^{1}$ Monthly number of herd-tests ranged from 12,619 to 14,341 .

${ }^{2}$ Monthly number of herd-tests ranged from 24,458 to 30,127 .

${ }^{3}$ Weighted for herds' milk yields; that is, represents the actual somatic cells in the total milk pool.

${ }^{4}$ Every herd-test contributed equally in calculating the arithmetic mean. 
$\mathrm{mL}$. For proposed NDHIA incremental standards, milk supply from noncompliant herds ranged monthly from 0.2 to $0.4 \%, 0.9$ to $1.2 \%$, and 2.8 to $3.6 \%$ for the same groups, respectively, about half that for the NMPF proposal. The noncompliant milk supply from the NMC-proposed standards would have been 0.6 to $0.9 \%$ for 550,000 cells $/ \mathrm{mL}$ and 3.2 to $4.5 \%$ for 400,000 cells $/ \mathrm{mL}$, which is slightly higher than for the current EU standard. Seasonal fluctuations in percentage of milk coming from noncompliant herds were similar to those based on herd noncompliance, except that increased noncompliant milk also was observed for April and May, especially as BTSCC limits became more restrictive. When limits for BTSCC between 400,000 and 500,000 cells $/ \mathrm{mL}$ were examined incrementally in the DHI herds using the frequency method of screening 3 of 5 BTSCC tests, a standard of 462,000 cells $/ \mathrm{mL}$ resulted in a milk noncompliance rate equal to that for the current EU standard (3.1\%).

As was observed with DHI data, the amount of milk that would have become noncompliant in FMO herds without herd management changes was substantially less (Table 5) than that indicative of the percentage of herd-tests (Table 2). For the NMPF-proposed limits of $600,000,500,000$, and 400,000 cells $/ \mathrm{mL}, 1.4,3.8$, and $10.1 \%$ of milk, respectively, would have been affected by the limits. Approximately one-third less milk would have been noncompliant using the geometric method compared with that using the frequency method at 400,000 cells/mL (6.7 and 10.1\%, respectively). With the NMC proposal, the noncompliant milk would have been $7.8 \%$ at the final level of 400,000 cells $/ \mathrm{mL}$.

Table 6 shows the relationship between the various alternatives proposed to change the BTSCC standards. Correlations between the various alternatives were generally between 0.35 and 0.74 . Not surprisingly, correlations were higher when the BTSCC levels were the same. The highest correlation (0.74) was between the frequency method proposed by NMPF and the geometric method proposed by NMC, both at 400,000 cells/mL. Correlation of the EU standard (the same as NDHIA-proposed 400,000 cells/mL) with the NMC-

Table 4. Percentages of milk supplied by US DHI herds noncompliant for bulk tank SCC (BTSCC) ${ }^{1}$ based on various standards by month

\begin{tabular}{|c|c|c|c|c|c|c|c|c|c|c|}
\hline End date & \multicolumn{4}{|c|}{$\begin{array}{l}3 \text { of } 5 \text { consecutive BTSCC } \\
\text { (cells } / \mathrm{mL} \text { ) tests }{ }^{2} \text { exceed: }\end{array}$} & \multicolumn{4}{|c|}{$\begin{array}{l}4 \text { consecutive } 3 \text {-mo geometric } \\
\left.\text { mean } \text { BTSCC }^{3} \text { (cells } / \mathrm{mL}\right) \text { exceed: }\end{array}$} & \multicolumn{2}{|c|}{$\begin{array}{l}\text { 3-mo geometric mean } \\
\text { BTSCC (cells/mL) } \\
\text { plus next BTSCC } \\
\text { test }^{4} \text { exceed: }\end{array}$} \\
\hline \multicolumn{11}{|l|}{2009} \\
\hline June & 0.3 & 0.9 & 2.0 & 5.7 & 0.0 & 0.4 & 1.1 & 3.2 & 0.8 & 3.6 \\
\hline September & 0.2 & 0.9 & 2.4 & 6.7 & 0.0 & 0.3 & 1.1 & 3.3 & 0.9 & 4.5 \\
\hline October & 0.2 & 1.0 & 2.3 & 6.9 & 0.0 & 0.3 & 1.2 & 3.6 & 0.8 & 4.1 \\
\hline November & 0.2 & 0.7 & 2.3 & 6.5 & 0.1 & 0.3 & 1.0 & 3.5 & 0.6 & 3.7 \\
\hline December & 0.1 & 0.7 & 2.1 & 5.8 & 0.1 & 0.2 & 1.0 & 3.4 & 0.6 & 3.2 \\
\hline \multicolumn{11}{|l|}{2010} \\
\hline January & 0.1 & 0.6 & 2.0 & 5.5 & 0.0 & 0.3 & 1.0 & 3.4 & 0.6 & 3.5 \\
\hline February & 0.1 & 0.6 & 1.8 & 5.2 & 0.0 & 0.2 & 0.9 & 2.9 & 0.7 & 3.4 \\
\hline August & 0.2 & 0.8 & 2.0 & 6.1 & 0.1 & 0.3 & 0.9 & 3.3 & 0.7 & 4.1 \\
\hline September & 0.2 & 0.9 & 2.2 & 6.3 & 0.1 & 0.3 & 0.9 & 3.0 & 0.9 & 4.4 \\
\hline October & 0.2 & 0.8 & 2.2 & 6.4 & 0.1 & 0.3 & 0.9 & 3.2 & 0.6 & 3.7 \\
\hline $\begin{array}{l}\text { Weighted mean } \\
\text { for last } 12 \text { mo }\end{array}$ & 0.2 & 0.7 & 2.0 & 5.8 & 0.1 & 0.3 & 1.0 & 3.1 & 0.7 & 3.7 \\
\hline $\begin{array}{l}{ }^{1} \text { Monthly numbe } \\
{ }^{2} \text { Last month of } 5 \\
{ }^{3} \text { Last month of } 4 \\
{ }^{4} \text { Month of test fo } \\
{ }^{5} \text { Current US BT } \\
{ }^{6} \text { BTSCC standar } \\
{ }^{7} \text { BTSCC standar } \\
{ }^{8} \text { Current Europe }\end{array}$ & $\begin{array}{l}\text { herd-tests } \\
\text { secutive } \mathrm{m} \\
\text { secutive } 3 \text { - } \\
\text { ing 3-mo } \mathrm{n} \\
\text { standard } \\
\text { oposed by } \\
\text { commende } \\
\text { Inion BTS }\end{array}$ & $\begin{array}{l}\text { anged from } \\
\text { nths. } \\
\text { no means. } \\
\text { ean. } \\
\text { FDA, } 1993 \\
\text { National M } \\
\text { by Nation } \\
\text { C standare }\end{array}$ & $\begin{array}{l}\text { Produce } \\
\text { DHIA }(\mathrm{J} \\
\text { Europa, } 2\end{array}$ & $\begin{array}{l}\text { attison, N } \\
\text { 9). }\end{array}$ & $\begin{array}{l}\text { 10b). } \\
\text { onal DHIA }\end{array}$ & Verona, W & II, personal & l communic & ion). & \\
\hline
\end{tabular}


Table 5. Percentages of milk supplied by US Federal Milk Marketing Order (FMO) herds noncompliant for bulk tank SCC (BTSCC) ${ }^{1}$ based on various standards by month

\begin{tabular}{|c|c|c|c|c|c|c|c|c|c|c|}
\hline \multirow[b]{2}{*}{ End date } & \multicolumn{4}{|c|}{$\begin{array}{l}3 \text { of } 5 \text { consecutive BTSCC } \\
\text { (cells } / \mathrm{mL} \text { ) tests }{ }^{2} \text { exceed: }\end{array}$} & \multicolumn{4}{|c|}{$\begin{array}{l}4 \text { consecutive } 3 \text {-mo geometric mean } \\
\left.\text { BTSCC }^{3} \text { (cells } / \mathrm{mL}\right) \text { exceed: }\end{array}$} & \multicolumn{2}{|c|}{$\begin{array}{c}\text { 3-mo geometric mean } \\
\text { BTSCC (cells/mL) plus } \\
\text { next BTSCC } \\
\text { test }^{4} \text { exceed: }\end{array}$} \\
\hline & $750,000^{5}$ & $600,000^{6}$ & $500,000^{6}$ & $400,000^{6}$ & $750,000^{7}$ & $600,000^{7}$ & $500,000^{7}$ & $400,000^{7,8}$ & $550,000^{9}$ & $400,000^{9}$ \\
\hline \multicolumn{11}{|l|}{2009} \\
\hline June & 0.3 & 1.5 & 4.0 & 10.1 & 0.1 & 0.8 & 2.6 & 7.3 & 1.5 & 7.6 \\
\hline July & 0.2 & 1.4 & 3.9 & 10.2 & 0.1 & 0.7 & 2.5 & 7.5 & 1.7 & 8.4 \\
\hline August & 0.2 & 1.5 & 4.1 & 10.9 & 0.1 & 0.7 & 2.5 & 7.7 & 1.9 & 9.4 \\
\hline September & 0.2 & 1.6 & 4.4 & 11.8 & 0.1 & 0.7 & 2.5 & 7.9 & 1.8 & 9.0 \\
\hline October & 0.2 & 1.5 & 4.3 & 11.5 & 0.1 & 0.7 & 2.6 & 7.8 & 1.5 & 7.6 \\
\hline November & 0.2 & 1.4 & 3.9 & 10.6 & 0.1 & 0.7 & 2.3 & 7.4 & 1.2 & 6.6 \\
\hline December & 0.1 & 1.1 & 3.2 & 9.0 & 0.1 & 0.6 & 2.1 & 6.5 & 1.1 & 6.0 \\
\hline \multicolumn{11}{|l|}{2010} \\
\hline January & 0.1 & 1.0 & 2.9 & 8.4 & 0.1 & 0.6 & 1.9 & 6.0 & 1.2 & 6.0 \\
\hline February & 0.2 & 1.1 & 3.0 & 8.2 & 0.1 & 0.6 & 1.8 & 5.7 & 1.4 & 6.8 \\
\hline March & 0.2 & 1.5 & 3.7 & 9.3 & 0.1 & 0.6 & 1.9 & 5.6 & 2.0 & 7.7 \\
\hline April & 0.2 & 1.6 & 4.1 & 9.6 & 0.1 & 0.7 & 2.3 & 6.0 & 1.8 & 7.2 \\
\hline May & 0.3 & 1.6 & 4.2 & 10.7 & 0.1 & 0.9 & 2.4 & 7.0 & 1.4 & 7.1 \\
\hline June & 0.2 & 1.4 & 3.9 & 10.0 & 0.1 & 0.8 & 2.5 & 7.0 & 1.6 & 7.8 \\
\hline July & 0.2 & 1.4 & 3.9 & 10.1 & 0.1 & 0.7 & 2.4 & 7.2 & 1.7 & 8.2 \\
\hline August & 0.2 & 1.5 & 4.2 & 11.2 & 0.1 & 0.6 & 2.4 & 7.0 & 1.9 & 9.3 \\
\hline September & 0.3 & 1.6 & 4.7 & 12.4 & 0.1 & 0.6 & 2.2 & 7.3 & 1.8 & 9.7 \\
\hline October & 0.3 & 1.6 & 4.3 & 11.9 & 0.1 & 0.7 & 2.3 & 7.5 & 1.1 & 6.0 \\
\hline $\begin{array}{l}\text { Weighted mean } \\
\text { for last } 12 \text { mo }\end{array}$ & 0.2 & 1.4 & 3.8 & 10.1 & 0.1 & 0.7 & 2.2 & 6.7 & 1.5 & 7.8 \\
\hline
\end{tabular}

${ }^{1}$ Monthly number of herd-tests ranged from 24,458 to 30,127 .

${ }^{2}$ Last month of 5 consecutive months.

${ }^{3}$ Last month of 4 consecutive 3-mo means.

${ }^{4}$ Month of test following 3-mo mean.

${ }^{5}$ Current US BTSCC standard (FDA, 1993).

${ }^{6}$ BTSCC standard proposed by National Milk Producers Federation (2010b).

${ }^{7}$ BTSCC standard recommended by National DHIA (J. Mattison, National DHIA, Verona, WI, personal communication).

${ }^{8}$ Current European Union BTSCC standard (Europa, 2009).

${ }^{9}$ BTSCC standard proposed by National Mastitis Council (A. Saeman, National Mastitis Council, Verona, WI, personal communication).

proposed standard of 400,000 cells/mL and with the NMPF-proposed standard of 500,000 cells/mL was also high (0.72 and 0.73 , respectively).

Producers might want to know the percentage of herds that would have had at least one noncompliance incident during the year based on using the current or proposed standards instead of monthly mean noncompliance rates. Percentages of DHI herds that were noncompliant at least once during the year using the frequency method (not shown) were 2.6, 7.1, 14.4, and $28.2 \%$ for BTSCC standards of $750,000,600,000$, 500,000 , and 400,000 cells/mL, respectively, which was at least twice as high as monthly noncompliance means of $0.9,2.7,6.2$, and $14.1 \%$ for DHI herds (Table 1 ). For FMO herds, noncompliance at least once during the year (not shown) was 2.9, 10.8, 20.9, and $37.7 \%$, which again was considerably higher than monthly noncompliance means of $1.0,4.7,11.0$, and $23.3 \%$ using the frequency method (Table 2). For the current EU standard, $17.7 \%$ of DHI herds and $29.3 \%$ of FMO herds were noncompliant at least once during the year (not shown) compared with $7.8 \%$ (Table 1) and $16.1 \%$ (Table 2) for monthly noncompliance, respectively.

\section{Effects of BTSCC by Herd Size}

Noncompliance rate for DHI herds differed markedly by herd size. Noncompliance generally decreased as herd size increased for both US (Figure 1a) and EU (Figure 1b) standards. Using the current US standard, $1.7 \%$ of the herd-tests resulted in noncompliance when herd size was $<50$ cows but $\leq 0.1 \%$ when any of the 4 herd size groups had $\geq 200$ cows. Under the current EU standard, noncompliance rate declined consistently from $10.6 \%$ when herd-tests had $<50$ cows to $0.5 \%$ when they had $\geq 1,000$ cows. Noncompliance rate using the final level of the NMC proposal (Figure 1c) showed a similar trend, declining from $12.3 \%$ for herd-tests with $<50$ cows to $0.6 \%$ for the largest herds. The percentage of DHI herds with one or more noncompliance violations per year (Figure 2) was often 2 to 3 times higher than the percentage of herds triggering noncompliant 
Table 6. Correlations between National Milk Producers Federation (NMPF), National DHIA (NDHIA), and National Mastitis Council (NMC) methods and levels for compliance ${ }^{1}$ to bulk tank SCC (BTSCC; $\times 1,000$ cells $/ \mathrm{mL}$ ) standards for DHI herd-tests from November 2009 through October 2010

\begin{tabular}{|c|c|c|c|c|c|c|c|c|c|c|c|}
\hline Method & $\begin{array}{l}\text { BTSCC } \\
\text { standard }\end{array}$ & \multicolumn{4}{|c|}{$\mathrm{NMPF}^{2}$} & \multicolumn{4}{|c|}{ NDHIA $^{3}$} & \multicolumn{2}{|c|}{$\mathrm{NMC}^{4}$} \\
\hline \multirow{3}{*}{ NMPF } & 600 & & 1.00 & 0.65 & 0.41 & 0.34 & 0.61 & 0.71 & 0.53 & 0.70 & 0.47 \\
\hline & 500 & & & 1.00 & 0.64 & 0.22 & 0.41 & 0.66 & 0.73 & 0.59 & 0.66 \\
\hline & 400 & & & & 1.00 & 0.14 & 0.26 & 0.43 & 0.70 & 0.38 & 0.74 \\
\hline \multirow{2}{*}{ NDHIA } & 750 & & & & & 1.00 & 0.53 & 0.32 & 0.19 & 0.35 & 0.18 \\
\hline & 400 & & & & & & & & 1.00 & 0.48 & 0.72 \\
\hline \multirow{2}{*}{ NMC } & 550 & & & & & & & & & 1.00 & 0.48 \\
\hline & 400 & & & & & & & & & & 1.00 \\
\hline
\end{tabular}

${ }^{1}$ Noncompliant $=0$ and compliant $=1$ based on 164,738 herd-tests.

${ }^{2}$ Three of 5 consecutive BTSCC (cells $/ \mathrm{mL}$ ) tests exceed the BTSCC level.

${ }^{3}$ Four consecutive 3-mo geometric mean BTSCC (cells $/ \mathrm{mL}$ ) exceed the BTSCC level.

${ }^{4}$ Three-month geometric mean BTSCC (cells/mL) plus next SCC test exceed the BTSCC level.

${ }^{5}$ Current European Union BTSCC standard (Europa, 2009).

violations on a monthly basis (Figure 1) within each herd-size category. For example, for the current US standard, $5.0 \%$ of herds with $<50$ cows have a violation at least once per year (Figure 2a), compared with $1.7 \%$ on a monthly basis (Figure 1a).

Similar to the DHI herds, a large difference in the percentage of herds that were noncompliant was observed when FMO herds were categorized by metric tons of milk shipped (Figure 3). The largest percentage of noncompliant herds for the current US standard and each of the proposed standards was observed in herds that shipped $<900$ t. Figure 4 shows the percentage of herds that would be noncompliant at least once yearly. For the 400,000 cells/mL standard using the frequency method, the percentage noncompliant was $44.5 \%$ for herds producing $<900 \mathrm{t}$ (Figure $4 \mathrm{a}$ ) compared with $8.0 \%$ for herds producing $>9,000 \mathrm{t}$. As the amount of milk shipped increased, the percentage of noncompliant shipments and herds decreased dramatically.

Within milk-shipped groups, percentages of noncompliant milk were similar to those for percentages of noncompliant herds (not shown) because stratification by herd size removed most of the relationship between milk quality and herd milk volume that exists across herd-size group. Most notable is that $24.3 \%$ of milk produced by herds producing $<900 \mathrm{t}$ would not have met the proposed frequency method at a standard of 400,000 cells/mL for the 12 mo from November 2009 through October 2010. About one-tenth (10.1\%) of all marketed milk would not have met the proposed standard of 400,000 cells/mL each month based on the frequency method.

The relationship between herd-size and BTSCC compliance for DHI herds was further examined by defining compliance as a binomial $(0=$ noncompliant; $1=$ compliant). Correlations (not shown) between monthly herd-tests and herd size increased as SCC standards became more restrictive: 0.04 for the current US standard and 0.05, 0.08, and 0.10 for the NMPF-proposed standards of $600,000,500,000$, and 400,000 cells $/ \mathrm{mL}$, respectively. Corresponding correlations for the geometric method were 0.02, 0.03, 0.05, and 0.08 (current EU standard). Correlations for the NMC method were 0.05 at a standard of 550,000 cells $/ \mathrm{mL}$ and 0.08 at a standard of 400,000 cells $/ \mathrm{mL}$. A low correlation is expected when standards are easy to meet; that is, correlations will be near zero when most herds have the same compliance code. The correlation increased as the standards became more restrictive.

\section{DISCUSSION}

The EU announcement that it plans to change the way that it enforces its BTSCC guidelines for imports is causing US authorities to reexamine current Pasteurized Milk Ordinance standards, with the possibility that some change may alleviate the complexity of dealing with multiple BTSCC criteria. Implementation of the NMPF and NMC proposals at a 400,000 cells/mL standard would be more restrictive and result in more herds, shipments, and milk not meeting the BTSCC standard compared with the current EU requirement because of the way the limits are executed. The NDHIA proposal at a 400,000 cells $/ \mathrm{mL}$ standard is the same as the EU method. For any given level, the geometric method resulted in a lower rate of noncompliance than did the frequency method.

That smaller herds have higher BTSCC than larger herds has been well documented (Wells and Ott, 1998; Norman et al., 2000; Jayarao et al., 2004). Although 

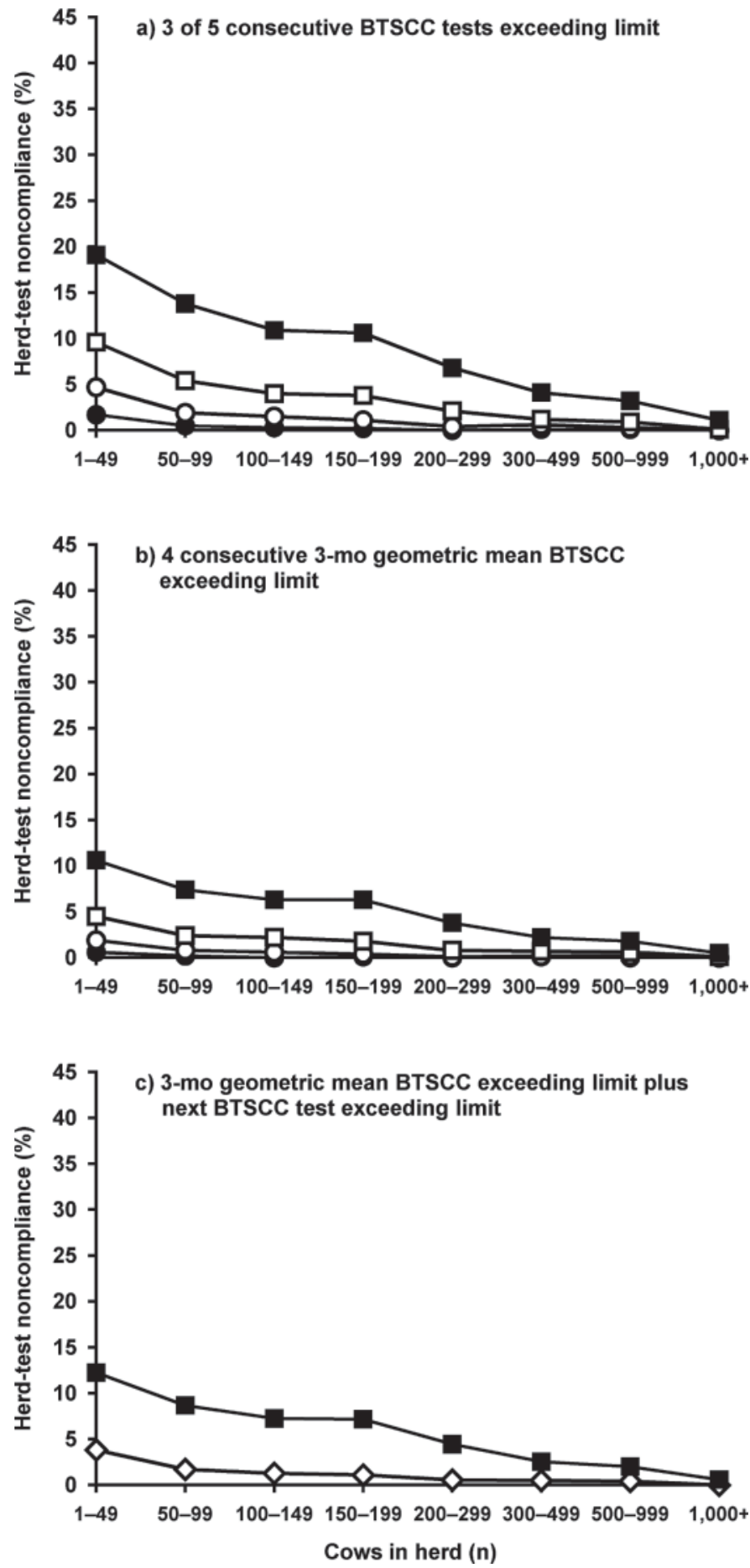

Figure 1. Noncompliance with bulk tank SCC (BTSCC) standards for DHI herd-tests by herd size calculated using (a) 3 of 5 consecutive BTSCC (cells $/ \mathrm{mL}$ ) tests exceeding limit, (b) 4 consecutive 3-mo geometric mean BTSCC exceeding limit, or (c) 3-mo geometric mean BTSCC exceeding limit plus next BTSCC test exceeding limit; BTSCC limits were 750,000 cells $/ \mathrm{mL}(\bullet), 600,000$ cells/mL (O), 550,000 cells/ $\mathrm{mL}(\diamond), 500,000$ cells $/ \mathrm{mL}(\square)$, and 400,000 cells $/ \mathrm{mL}(\mathbf{\square})$.
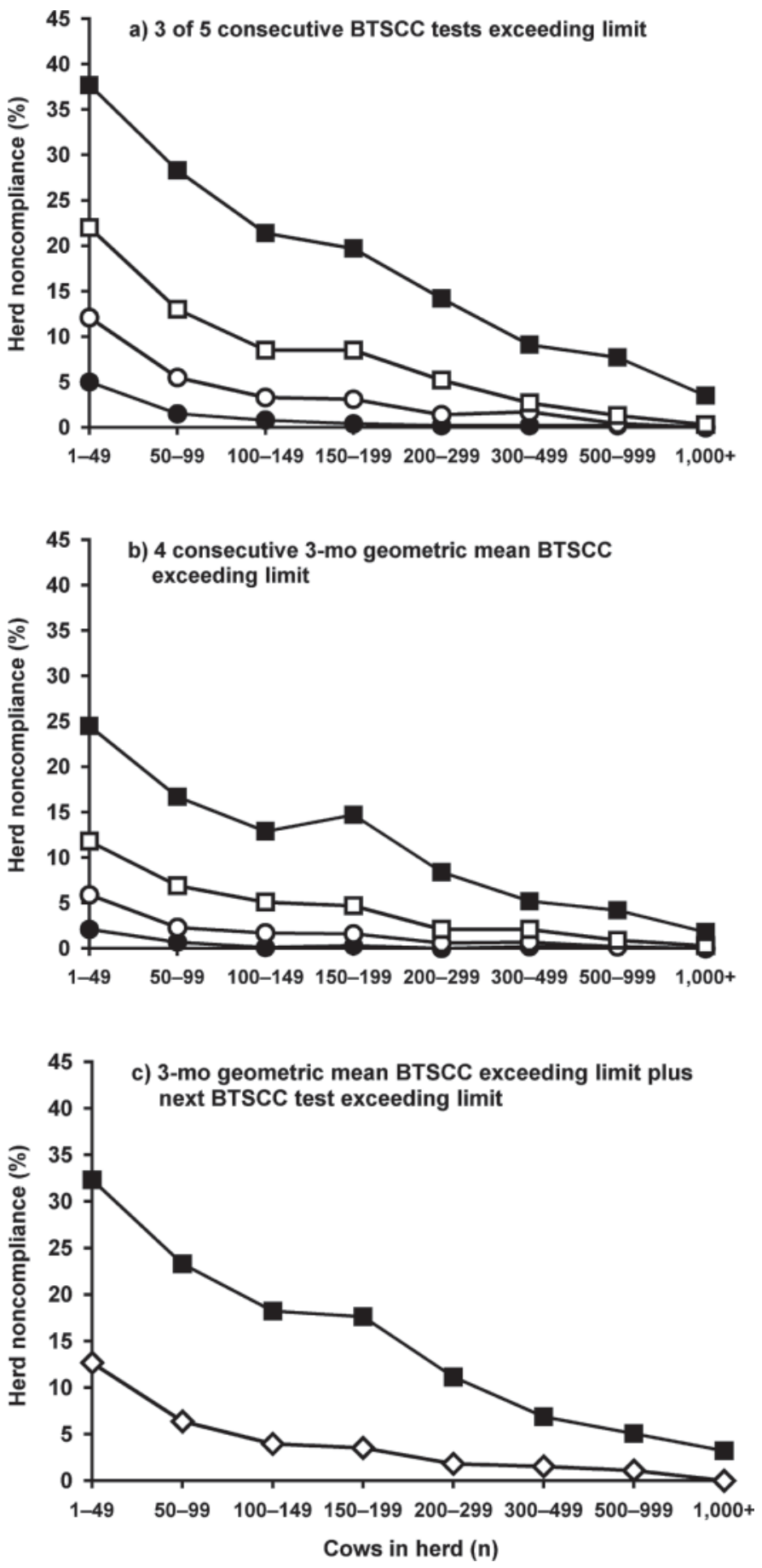

Figure 2. Noncompliance with bulk tank SCC (BTSCC) standards at least once per year for DHI herds by herd size calculated using (a) 3 of 5 consecutive BTSCC (cells $/ \mathrm{mL}$ ) tests exceeding limit, (b) 4 consecutive 3-mo geometric mean BTSCC exceeding limit, or (c) 3-mo geometric mean BTSCC exceeding limit plus next BTSCC test exceeding limit; BTSCC limits were 750,000 cells/mL $(\bullet), 600,000$ cells/mL (O), 550,000 cells/mL ( $\diamond), 500,000$ cells/mL $(\square)$, and 400,000 cells/mL (ם). 

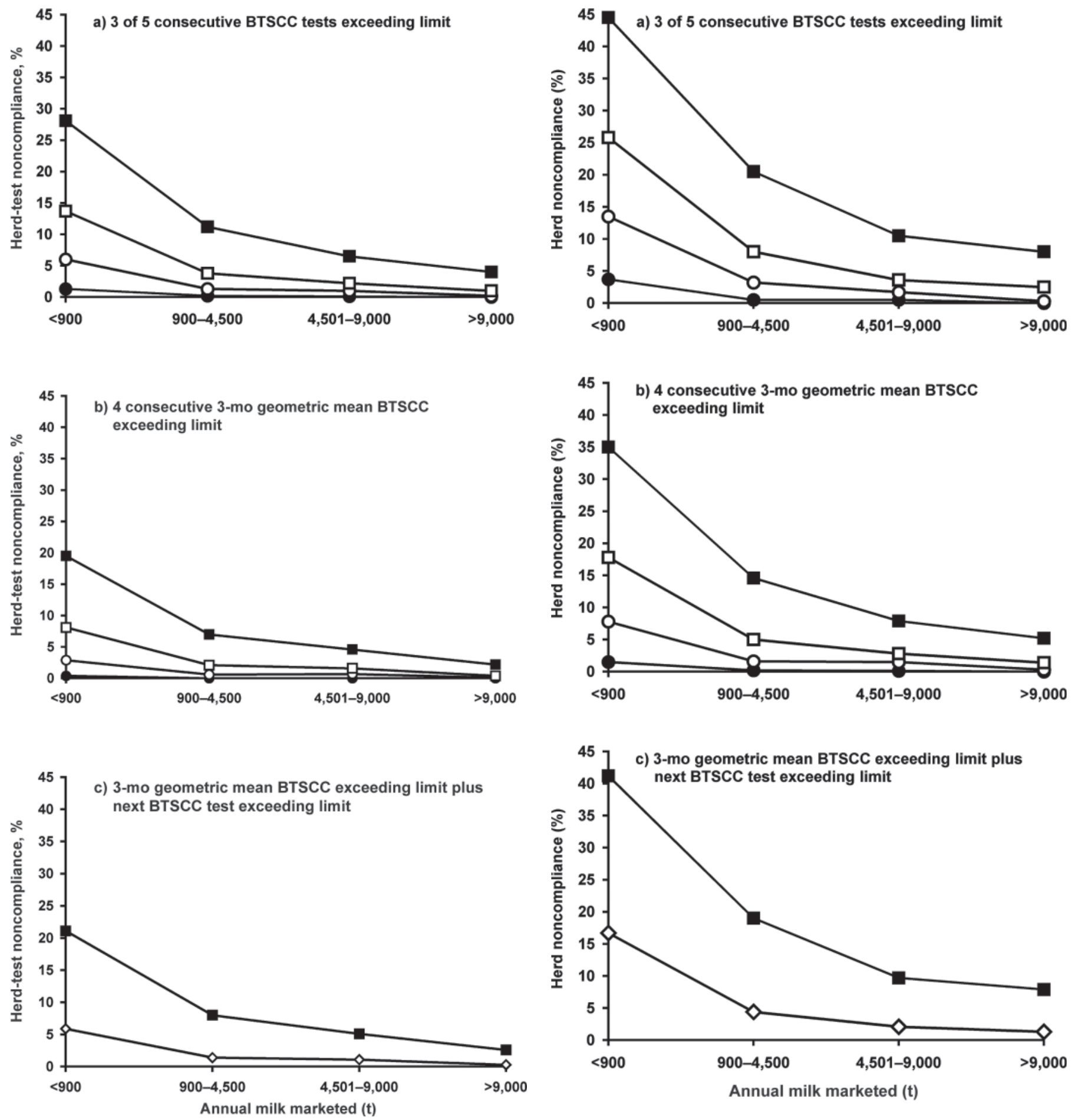

Figure 3. Noncompliance with bulk tank SCC (BTSCC) standards for Federal Milk Order herd-tests by annual milk marketed calculated using (a) 3 of 5 consecutive BTSCC (cells/mL) tests exceeding limit, (b) 4 consecutive 3-mo geometric mean BTSCC exceeding limit, or (c) 3-mo geometric mean BTSCC exceeding limit plus next BTSCC test exceeding limit; SCC limits were 750,000 cells/mL (•), 600,000 cells/ $\mathrm{mL}(\bigcirc), 550,000$ cells $/ \mathrm{mL}(\diamond), 500,000$ cells $/ \mathrm{mL}(\square)$, and 400,000 cells $/ \mathrm{mL}$

Figure 4. Noncompliance with bulk tank SCC (BTSCC) standards at least once yearly for Federal Milk Order herds by annual milk marketed calculated using (a) 3 of 5 consecutive BTSCC (cells $/ \mathrm{mL}$ ) tests exceeding limit, (b) 4 consecutive 3-mo geometric mean BTSCC exceeding limit, or (c) 3-mo geometric mean BTSCC exceeding limit plus next BTSCC test exceeding limit; BTSCC limits were 750,000 cells/ $\mathrm{mL}(\bullet), 600,000$ cells $/ \mathrm{mL}(\bigcirc), 550,000$ cells $/ \mathrm{mL}(\diamond), 500,000$ cells $/ \mathrm{mL}$ $(\square)$, and 400,000 cells/mL ( 
no direct investigations of management practices have been made to account for the increased BTSCC in small herds, other studies have documented differences among herds with varying BTSCC means. For example, Wenz et al. (2007) reported that herds with a BTSCC of $<200,000$ cells $/ \mathrm{mL}$ were almost twice as likely to use coliform vaccine and antibiotic treatment at the end of lactation compared with herds with a BTSCC of $>400,000$ cells $/ \mathrm{mL}$.

Herds with elevated BTSCC may be expected to apply antibiotic therapy more frequently and as a result may have increased frequency of violations because of antibiotic residues in bulk-tank milk shipments. Ruegg and Tabone (2000) studied BTSCC and antibiotic residue frequency for 805,772 grade A milk samples. Risk of antibiotic violations increased from $1.0 \%$ in herds with the lowest BTSCC to $7.1 \%$ in herds with the highest BTSCC.

Which alternative for BTSCC standard is best for the US dairy industry and consumers is not obvious; therefore, selection might be assisted by examining the strength of relationship between alternatives and percentages of herds that are excluded by the various methods. Another consideration might be which alternative best leads to improved animal health and well-being, lower health costs, reduced cost of production, and even lower risk of antibiotic contamination in the bulk tank. However, no information regarding those concerns could be gleaned from these DHI and FMO data. Because all the alternative standards being considered are more stringent than the current US standard, US producers will need to place more emphasis on preventing and combating mastitis as well as on directed culling to improve milk quality.

Schukken et al. (1992) and Sargeant et al. (1998) described the results from the BTSCC reduction program in Ontario, Canada. The total decrease in SCC over 10 yr was 80,000 cells $/ \mathrm{mL}$ (Sargeant et al., 1998). Schukken et al. (1992) stated that the penalty system used was sufficient to lower SCC levels. They reported that herds with high BTSCC had the most additional violations during adoption of more stringent requirements when new standards were implemented. The same is likely to be the case in the United States. Over the last $9 \mathrm{yr}$, the DHI SCC levels in the United States have declined 91,000 cells/mL even though federal standards have not changed. The US DHI SCC decline was likely caused primarily by high incentives and premiums required in the FMO areas and provided voluntarily to producers throughout the United States. The mean SCC is as low in the United States as in most other major dairy countries even though the US federal standard is considerably higher. Thus, the rapid decline in SCC that has already taken place in the United States seems to preclude the likelihood of the same magnitude of decline as in Canada if standards were tightened.

Considerable discussion has already taken place within the various organizations on what should be the optimum SCC standard for the United States. A strong case can be made that if most other countries have uniform regulations, it makes sense for the United States to accept theirs. Clear advantages exist for the importer (or exporter) of the various countries to be working with a single set of standards for all their producers. The various US organizations that have endorsed proposals have somewhat different interests in whom they represent. It is somewhat surprising that NMPF, which opposed many earlier efforts to lower the SCC standard, has now taken a position that would make the noncompliance rate for its producers twice as high as that from the EU standard. The NMC standard is only slightly more restrictive than the EU standard, yet deals with a milk quality issue much faster than does the EU. This may be a positive feature, but this would then make all other countries meet a standard more restrictive than those they currently have. The decision to not lower the US national standard is no doubt projecting a negative image onto the quality of US milk, much of which is not deserved when one considers that the mean SCC is as low as in most other major dairy countries.

Evidence is strong that DHI herds have lower BTSCC than do non-DHI herds. The difference in BTSCC means between DHI and FMO herds provides circumstantial evidence that DHI herds have superior udder health and mastitis management practices to other herds. In FMO herds that do not test individual cows, identifying cows that are contributing to high BTSCC would be difficult. Thus, DHI herds may be expected to have lower herd mean BTSCC (Lievaart et al., 2009). Although BTSCC does not equate to clinical mastitis incidence, it may be somewhat correlated. Erskine et al. (1988) reported a low prevalence of intramammary infections from all major pathogens in herds with low SCC and a high prevalence of infection with Streptococcus agalactiae and Staphylococcus aureus in herds with high SCC. In contrast, Barkema et al. (1998) did not find a significant difference in the incidence rate of clinical mastitis between herds with a high and low BTSCC.

Differences in SCC between DHI and non-DHI herds are likely even larger than those observed between DHI and FMO herds, considering that many FMO herds are also in DHI programs and that DHI SCC overestimates BTSCC, as shown by Lievaart et al. (2009). Although DHI herds often withhold questionable quality milk from the bulk tank, it still is included in the DHI herd means. Unfortunately, because of those differences, 
means in Table 3 are not entirely comparable. If information on which FMO herds were in DHI programs had been available, a more comprehensive evaluation could have been made. The availability of monthly SCC data for individual cows, which is common for DHI herds, is a valuable benefit that likely will increase substantially in worth as producers have to deal with increased noncompliance due to more restrictive standards. Not surprisingly, DHI producers appear to be more concerned about milk quality and probably have implemented monthly testing at least in part to help achieve the production of low SCC milk. Herds not in DHI programs will have difficulty in reducing the noncompliance rate using BTSCC alone.

Changes in the SCC standards that will likely be forced upon US producers (have already arrived, in a few cases) seem destined to be as disruptive as any changes they have faced in some time. When one considers that the noncompliance rate in a typical month has been near $1 \%$ but may be increasing to 8 to $24 \%$ (unless management is altered) under the various proposals being considered, it seems that considerably more effort to deal with the issue will be needed than is anticipated at this time. Premium payments based on SCC have been highly effective in reducing SCC means, so continuation of these should be encouraged regardless of any changes in standards.

\section{ACKNOWLEDGMENTS}

Cooperation of the dairy records processing centers (AgriTech Analytics, Visalia, CA; AgSource Cooperative Services, Verona, WI; DHI Computing Service, Provo, UT; and Dairy Records Management Systems, Raleigh, NC, and Ames, IA) in supplying lactation data that included milk yields and SCS is greatly appreciated. Access to FMO data from the Central, Upper Midwest, Mideast, and Southwest Milk Market Administrators is appreciated also. Assistance of $\mathrm{K}$. R. Vorgert (Agricultural Marketing Service, USDA, Lisle, IL) and C. B. Covington (Clemmons, NC) in providing information on EU and US milk standards is acknowledged. Valuable suggestions by S. M. Hubbard (Animal Improvement Programs Laboratory, ARS, USDA, Beltsville, MD) and 3 anonymous reviewers for the Journal of Dairy Science are greatly appreciated.

\section{REFERENCES}

Adkinson, R. W., R. H. Gough, R. Graham, and A. Yilmaz. 2001. Implications of proposed changes in bulk tank somatic cell count regulations. J. Dairy Sci. 84:370-374.

Agricultural Marketing Service. 2009. Instructions for dairy inspection and grading service. DA Instruction No. 918-I. USDA, Washington, DC.
Animal Improvement Programs Laboratory. 2011. DHI participation as of January 1, 2011 (DHI Report K-1). Accessed August 11, 2011. http://aipl.arsusda.gov/publish/dhi/dhi11/partall.html.

Barkema, H. W., Y. H. Schukken, T. J. G. M. Lam, M. L. Beiboer, H. Wilmink, G. Benedictus, and A. Brand. 1998. Incidence of clinical mastitis in dairy herds grouped in three categories by bulk milk somatic cell counts. J. Dairy Sci. 81:411-419.

Barkema, H. W., J. D. van der Ploeg, Y. H. Schukken, T. J. G. M. Lam, G. Benedictus, and A. Brand. 1999. Management style and its association with bulk milk somatic cell count and incidence rate of clinical mastitis. J. Dairy Sci. 82:1655-1663.

Brightling, P., A. Hope, A. Thompson, and R. Dyson. 2005. Countdown Downunder 2001-2004: Building Industry Capacity to Control Mastitis and Manage Milk Quality. Dairy Australia, Southbank, Victoria, Australia.

Burggraff, J. 2010. EU enforces restrictions on somatic cell counts Dairy Star, Apr. 26, 9:25 a.m. Accessed August 11, 2011. http:// www.dairystar.com/main.asp?SectionID $=1 \&$ SubSectionID $=1 \& \mathrm{Ar}$ ticle $\mathrm{ID}=4510 \& \mathrm{TM}=69003.02$.

Canadian Food Inspection Service. 2005. National Dairy Code, Production and Processing Regulations, 4th ed., amended July, 2005. Accessed August 11, 2011. http://www.cfis.agr.ca/english/regcode/ndrc/amdmt_jul_and_oct2005/2005_ppr_e.pdf.

Dufour, S., A. Fréchette, H. W. Barkema, A. Mussell, and D. T. Scholl. 2011. Invited review: Effect of udder health management practices on herd somatic cell count. J. Dairy Sci. 94:563-579.

Dumas, C. R. 2010. Federation takes on somatic cell count. Capital Press, Nov. 24. Accessed August 11, 2011. http://www.capitalpress.com/content/CRD-milk-standard-w-art-111910.

Erskine, R. J., R. J. Eberhart, L. J. Hutchinson, S. B. Spencer, and M. A. Campbell. 1988. Incidence and types of clinical mastitis in dairy herds with high and low somatic cell counts. J. Am. Vet. Med. Assoc. 192:761-765.

Europa. 2009. Regulation (EC) No. 853/2004 of the European Parliament and of the Council of 29 April 2004 laying down specific hygiene rules for food of animal origin (OJ L 226, 25.6.2004, p. 22) [with successive amendments and corrections consolidated]. Accessed August 11, 2011. http://eur-lex.europa.eu/LexUriServ/ LexUriServ.do?uri=CONSLEG:2004R0853:20071114:EN:PDF.

FDA. 1991. Actions of the 1991 National Conference on Interstate Milk Shipments, August 22 memorandum from Milk Safety Branch. Accessed August 11, 2011. http://www.fda.gov/Food/ FoodSafety/Product-SpecificInformation/MilkSafety/CodedMemoranda/MemorandaofConferenceActions/ucm073723.htm.

FDA. 1993. Grade "A" Pasteurized Milk Ordinance, 1993 Revision. US Department of Health and Human Services, Washington, DC.

FDA. 2009. Grade "A" Pasteurized Milk Ordinance, 2009 Revision. US Department of Health and Human Services, Washington, DC.

Gillibrand, K. 2010. After Senator Gillibrand took action to improve milk quality and bolster exports, National Milk steps up to the plate to raise milk standards. Press release, Nov. 10. Accessed August 11, 2011. http://gillibrand.senate.gov/newsroom/press/ release/?id=faae1c5d-cbc2-42b1-8b6a-134c0d810e23.

govtrack.us. 2011. S. 458: Milk Quality Standards Act of 2011. Accessed August 11, 2011. http://www.govtrack.us/congress/bill. $\operatorname{xpd}$ ?bill $=$ s112- 458 .

International Dairy Federation. 1997. Recommendation for presentation of mastitis related data. Bulletin 321/1997. Int. Dairy Fed., Brussels, Belgium.

Jayarao, B. M., S. R. Pillai, A. A. Sawant, D. R. Wolfgang, and N. V. Hegde. 2004. Guidelines for monitoring bulk tank milk somatic cell and bacterial counts. J. Dairy Sci. 87:3561-3573.

Johnson, R. 2010. Letter asks FDA to wade into SCC fray. Agri-View, July 1, 2:38 p.m. Accessed October 13, 2011. http://www.agriview.com/news/dairy/letter-asks-fda-to-wade-into-scc-fray/article_ 41498942-c86e-58ff-8c92-ce22f77b5a18.html.

Lievaart, J., H. W. Barkema, H. Hogeveen, and W. Kremer. 2009. Reliability of the bulk milk somatic cell count as an indication of average herd somatic cell count. J. Dairy Res. 76:490-496.

Maryland \& Virginia Milk Producers Cooperative Association. 2011. Somatic cell count scrutiny continues. Pipeline 27(5). Accessed 
August 12, 2011. https://www.mdvamilk.com/Pipeline/Jun11PL. pdf.

National Milk Producers Federation. 2010a. EU somatic cell count standard still unresolved. News for Dairy Co-Ops 68(8). Accessed August 11, 2011. http://nmpf.org/latest-news/news-dairy-coops/ articles/eu-somatic-cell-count-standard-still-unresolved.

National Milk Producers Federation. 2010b. NMPF delegates vote to lower SCC limit to 400,000 in 2014. News for Dairy Co-Ops 68(11). Accessed August 11, 2011. http://nmpf.org/latest-news/ news-dairy-coops/articles/nmpf-delegates-vote-to-lower-scc-limitto-400-000-in-2014.

National Milk Producers Federation. 2011. Proposal to reduce somatic cells counts defeated by National Conference on Interstate Milk Shipments. Press release, May 4, 2011. Accessed August 11, 2011. http://nmpf.org/latest-news/press-releases/may-2011/proposalto-reduce-somatic-cells-counts-defeated-by-national-con.

New Zealand Food Safety Authority. 2010. Code of Practice: Additional Measures for Raw Milk Products. Accessed August 31, 2011. http://www.foodsafety.govt.nz/elibrary/industry/raw-milkproducts-cop/code-of-practice-additional-measures-for-raw-milkproducts.pdf.

Norman, H. D. 2010. Recent trends in mastitis and fertility indicators in the United States and reasons for change. Page 142 in Book of Abstracts of the 61st Annual Meeting of the European Association for Animal Production. Wageningen Academic Publishers, the Netherlands.

Norman, H. D., T. A. Cooper, and F. A. Ross Jr. 2011a. Somatic cell counts of milk from Dairy Herd Improvement herds during 2010 AIPL Res. Rep. SCC12(2-11). Accessed August 11, 2011. http:// aipl.arsusda.gov/publish/dhi/dhi11/sccrpt.htm.

Norman, H. D., R. H. Miller, J. R. Wright, and G. R. Wiggans. 2000 Herd and state means for somatic cell count from Dairy Herd Improvement. J. Dairy Sci. 83:2782-2788.

Norman, H. D., J. R. Wright, and R. H. Miller. 2011b. Consequence for dairy herds in the United States of imposing different standards for somatic cell count. Pages 119-120 in Proc. 50th Annu. Mtg. Natl. Mastitis Counc., Arlington, VA. Natl. Mastitis Counc., Verona, WI.

Ruegg, P. L., and T. J. Tabone. 2000. The relationship between antibiotic residue violations and somatic cell counts in Wisconsin dairy herds. J. Dairy Sci. 83:2805-2809.
Sargeant, J. M., Y. H. Schukken, and K. E. Leslie. 1998. Ontario bulk milk somatic cell count reduction program: Progress and outlook. J. Dairy Sci. 81:1545-1554.

Schukken, Y. H., K. E. Leslie, A. J. Weersink, and S. W. Martin. 1992. Ontario bulk milk somatic cell count reduction program: 1. Impact on somatic cell counts and milk quality. J. Dairy Sci. 75:3352-3358

Shook, G., and P. Ruegg. 1999. Geometric mean somatic cell counts: What they are; what they do. Pages 93-100 in Proc. 38th Annu. Mtg. Natl. Mastitis Counc., Arlington, VA. Natl. Mastitis Counc. Madison, WI.

Spomer, D. R. 1998. Bridging the gap between public health and consumer demand for high quality product. Pages $44-46$ in Proc. 37th Annu. Mtg. Natl. Mastitis Counc., St. Louis, MO. Natl. Mastitis Counc., Madison, WI.

USDA. 2007. Dairy 2007, Part I: Reference of Dairy Cattle Health and Management Practices in the United States, 2007. \#N480.1007. USDA-APHIS-VS, CEAH, Fort Collins, CO.

Veterinary Services. 2007. Determining U.S. milk quality using bulk tank somatic cell counts, 2005. National Animal Health Monitoring System, Animal and Plant Health Inspection Service, Fort Collins, CO.

Veterinary Services. 2010. Determining U.S. milk quality using bulk tank somatic cell counts, 2009. National Animal Health Monitoring System, Animal and Plant Health Inspection Service, Fort Collins, CO.

Wells, S. J., and S. L. Ott. 1998. What is the quality of the U.S milk supply? Pages 10-19 in Proc. 37th Annu. Mtg. Natl. Mastitis Counc., St. Louis, MO. Natl. Mastitis Counc., Madison, WI.

Wenz, J. R., S. M. Jensen, J. E. Lombard, B. A. Wagner, and R. P. Dinsmore. 2007. Herd management practices and their association with bulk tank somatic cell count on United States dairy operations. J. Dairy Sci. 90:3652-3659.

World Trade Organization. 1998. The WTO Agreements Series 2: General Agreement on Tariffs and Trade. WTO Publications, Geneva, Switzerland. 